\title{
CONVALESCENT SERA: TREATMENT FOR NOVEL AND ENIGMATIC COVID-19
}

\author{
Dr.Suman Saurabh Gupta \\ Department of Pathology, \\ Postgraduate Resident, \\ Dy Patil Medical College, \\ Kolhapur,Maharashtra \\ Dr.Priyanka Chandak \\ Postgraduate Resident, \\ SCGMC -Nanded, \\ Maharashtra
}

\author{
Dr.Arun Kumar Gupta \\ MD Obstetrics \& Gynaecology, \\ Jaora,Madhya Pradesh
}

\author{
Dr.Juhi Kumari \\ MBBS, \\ BJMC Ahembdabaad, \\ Gujrat
}

Article DOI: https://doi.org/10.36713/epra4354

\begin{abstract}
As of early 2020, humanity is attempt a pandemic in severe acute metabolic process syndrome coronavirus a pair of (SARS-CoV-2).SARS-CoV-2 causes coronavirus sickness, abbreviated as COVID-19. With COVID-19, the degree of unwellness varies, ranging from well to sudden and fatal. the world Health Organization estimates that serious unwellness could occur in as several as thirteen.8\% of cases and six. $1 \%$ area unit essential. This Viewpoint argues that human convalescent humour is Associate in Nursing possibility for bar and treatment of COVID-19 sickness. convalescent sera may well be accustomed treat people with early symptoms and stop sickness in those exposed. Hence, as we tend to area unit inside the inside of a worldwide pandemic, we tend to advocate that establishments think about the emergency use of convalescent sera and start preparations as presently as doable. Time is of the essence.
\end{abstract}

KEYWORDS- Plasmapheresis, Morbilli, Grippe, Coronavirus, Monoclonal Antibody

\section{INTRODUCTION}

As of early 2020, humanity is endeavour an endemic in severe acute metastasis syndrome coronavirus a pair of (SARS-CoV-2).SARS-CoV-2 causes coronavirus unwellness, abbreviated as COVID-19. Associate in Nursing calculable a hundred,000 people have already been infected with nearly 3300 deaths attributed to the unwellness (termed COVID-19) [1]. the design for effective treatment is afoot with multiple investigations current across the world . Chinese authorities have reportable success treating infected patients with given plasma from survivors of the ill health, the planned profit being protecting antibodies fashioned by the survivors [2]. Plasma transfusion and blood purification are not novel therapies, which we tend to propose therapeutic plasma exchange as a doable treatment for sudden COVID-19. With COVID-19, the degree of ill health varies, ranging from well to sudden and fatal. the world Health Organization estimates that serious ill health could occur in as several as thirteen. $8 \%$ of cases and half-dozen. $1 \%$ square measure vital [3]. once sudden, patients could develop infection, acute metastasis distress syndrome (ARDS), and/or multiple organ failure which are not distinctive to coronavirus. whereas treatment of the virus itself is definitely desired, treatment of the general response is maybe aiming to be the additional necessary side of care and can be sharply wanted. This host response to infection has been well delineate and involves a fancy interaction of protein storm, inflammation, epithelial tissue disfunction, and pathologic action [4-8]. The pathway is common to multiple inciting events and has been the target of treatment for years, with therapeutic plasma exchange unambiguously providing profit on multiple levels by removing inflammatory cytokines, stabilising epithelial tissue membranes, and resetting the hypercoagulable state $[4,8,9]$. This Viewpoint argues that human convalescent humour|liquid body substance|bodily fluid|body fluid|humor|humour\} is Associate in Nursing possibility for interference and 
treatment of COVID-19 unwellness that might be apace offered once there square measure enough numbers of people World Health Organization have recovered and should present immunoglobulincontaining serum.

\section{WHAT'S PLASMAPHERESIS....}

Plasmapheresis, that is outlined as a result of the removal of plasma, square measure usually either "adjusted plasma" or "exchange of plasma". the previous is outlined as selective withdrawal of bound (un)-pathological plasma elements in many ways in which like insertion then returning the remained donor plasma to him, the latter is non-selective removal of all elements of plasma to provide blood products for injection into patients or to be used as a result of the input of transfusion industrial plant or to induce eliminate the infective agent contained plasma before compensating for the amount losses with Associate in Nursing equal volume of plasma or additional unremarkably, exchange plasma with a substitute fluid (colloid or crystalloid) like simple protein. pheresis was divided typically into 2 groups:

1-Plasma product by donor pheresis 2- Therapeutic pheresis

Therapeutic plasma exchange or TPE square measure usually attributed to plasma that exit from the body of patient then remunerated by any quite replacement fluid volumes to support neurmolemic scenario of patients. pheresis is presently used as a therapeutic modality throughout a giant choice of conditions. Generally, pheresis is utilized once a substance at intervals the plasma, like immune serum globulin, is acutely poisonous and should be with efficiency removed. Myriad conditions constitute this class, as well as medicine, hematological, metabolic, medicine, rheumatologic, and urinary organ diseases, additionally as intoxications, which is able to be treated with pheresis.

\section{IS CONVALESCENT SERA ACT AS A MEDICAL CARE/ PASSIVE PROTEIN THERAPY}

Passive protein medical care involves the administration of Associate in Nursing the bodies against a given agent to a vulnerable individual for the aim of preventing or treating an disease due to that agent. In distinction, active vaccination needs the induction of Associate in Nursing reaction that takes time to develop and varies looking forward to the immunizing agent recipient. Thus, passive protein administration is that the sole suggests that of providing immediate immunity to vulnerable persons $(10,11)$. expertise from previous outbreaks with alternative coronaviruses, like SARS-CoV-1, shows that such convalescent sera contain neutralizing antibodies to the relevant virus (12). at intervals the case of SARS-CoV-2, the anticipated mechanism of action by that passive protein medical care would mediate protection is infective agent neutralization. However, alternative mechanisms might even be doable, like antibody-dependent cellular toxicity and/or body process. doable sources of protein for SARS-CoV-2 square measure human convalescent sera from people World Health Organization have recovered from COVID-19, mAbs, or preparations generated in bound animal hosts, like genetically designed cows that manufacture human protein (13). A general principle of passive protein medical care is that it's less complicated once used for prevention than for treatment of unwellness. once used for medical care, protein is best once administered shortly when the onset of symptoms. the principle for temporal variation in effectiveness is not well understood however might mirror that passive protein works by neutralizing the initial substance, that is maybe aiming to be abundant smaller than that of established unwellness (14). Another rationalization is that protein works by modifying the inflammatory response, that is to boot additional simply achieved throughout the initial reaction, a stage which is able to be well (15). For passive protein medical care to be effective, a enough quantity of protein should be administered. once given to a vulnerable person, this protein can flow into at intervals the blood, reach tissues, and provide protection against infection. looking forward to the protein quantity and composition, the protection presented by the transferred immune serum globulin will last from weeks to months.

\section{HISTORICAL PRECEDENTS}

In the early twentieth century convalescent sera was used to stem outbreaks of microorganism diseases like infectious disease (16), morbilli $(17,18)$, mumps (19), and grippe (20). A retrospective metaanalysis of eight studies on the employment of convalescent sera involving 1703 patients throughout the $1918 \mathrm{H} 1 \mathrm{~N} 1$ grippe virus pandemic urged that those who received liquid body substance had lower mortality (21). though the effectivity of convalescent sera varied with the virus and thus the study, there was accord at the time that this intervention was helpful, and it had been used in various outbreaks. it's noteworthy that traditionally, convalescent sera were developed and used in several cases while not the means that to measure protein titers or data regarding microorganism serotypes, and in clinical studies that did not meet trendy criteria for organisation or dazzling. a lot of recently, convalescent liquid body substance was used throughout microorganism epidemics. at intervals the 2009-2010 H1N1 grippe virus pandemic, convalescent liquid body substance protein preparations obtained by apheresis were used to treat people with severe H1N1 2009 infection requiring treatment (22). Serum-treated people manifested reduced metabolic process microorganism 
burden, liquid body substance protein responses, and mortality (22). Convalescent liquid body substance was additionally used within the 2013 West African Ebola fever epidemic.

\section{RISK \& ADVANTAGES}

COVID-19 convalescent sera are usually used for either bar of infection or treatment of unwellness. throughout a prophylactic mode, the advantage of convalescent liquid body substance administration is that it will stop infection and resulting unwellness in those who are at high risk for unwellness, like vulnerable people with underlying medical conditions, health care suppliers, and folks with exposure to confirmed cases of COVID-19. Passive protein administration to prevent unwellness is already used in clinical follow. recently, a polyclonal hyperimmune simple protein (RSV-IG) ready from samples of donors with high liquid body substance titers of RSV neutralizing protein was used, however these preparations have currently been replaced by palivizumab, a humanized murine mAb. Used therapeutically, convalescent liquid body substance would be administered to those with clinical unwellness in an effort to cut back their symptoms and mortality. The effectivity of these approaches cannot be inferred while not finishing a controlled run - supported the historical expertise with protein administration, it are usually anticipated that protein administration would be easier in preventing unwellness than at intervals the treatment of established unwellness (20).

Risks of passive administration of convalescent sera constitute 2 classes, proverbial and theoretical. proverbial risks are those associated with transfer of blood substances, that embody accidental infection with another disease agent and reactions to liquid body substance constituents, together with medical specialty reactions like serum sickness. With trendy blood banking techniques that screen for blood-borne pathogens and match the blood type of donors and recipients, the risks of unknowingly transferring proverbial infectious agents or triggering transfusion reactions are low. However, convalescent sera used during a therapeutic mode would seemingly be administered to people with respiratory organ unwellness, in whom plasma infusion carries some risk for transfusion connected acute respiratory organ injury (TRALI) (23), and this might be a thought at intervals the risk-benefit assessment. The theoretical risk involves the development of protein dependent sweetening of infection (ADE). potable will occur in many microorganism unwellnesss associate degreed involves an sweetening of disease at intervals the presence of bound antibodies. For coronaviruses, many mechanisms for potable are delineated, and there is the theoretical concern that antibodies to a minimum of one style of coronavirus may enhance infection to a distinct microorganism strain (24). it's getting to be potential to predict the danger of potable of SARS-CoV-2 by experimentation, as projected for MERS (24). Since the projected use of convalescent sera at intervals the COVID-19 epidemic would believe preparations with high titers of neutralizing protein against constant virus, SARS2-CoV-2, potable may even be unlikely. The on the market proof from the employment of convalescent sera in patients with SARS1 and MERS (25), and anecdotal proof from its use in 245 patients with COVID-19 (26), recommend it's safe.

Another theoretical risk is that protein administration to those exposed to SARS-CoV-2 might stop unwellness in a manner that attenuates the immune response, feat such people vulnerable to resulting reinfection. In this regard, passive protein administration before vaccination with metabolic process syncytial virus was rumoured to attenuate humoral however not cellular immunity (27). This concern may well be investigated as a region of a run by measurement immune responses in those exposed and treated with convalescent sera to prevent unwellness. If the danger tried real, these people may well be unsusceptible against COVID-19 once a immunogen becomes on the market.

\section{PREPARATION AND PROPOSED USE}

To deploy convalescent liquid body substance administration for COVID-19 the following six conditions should be met:

(i) Convenience of a population of donors United Nations agency have recovered from the unwellness and will give convalescent serum;

(ii) Blood banking facilities to method the liquid body substance

donations; (iii) Convenience of assays, together with serologic assays, to notice SARS-CoV-2 in liquid body substance and medical specialty assays to measure microorganism neutralization;

(iv) Medical specialty laboratory support to perform these assays; (v) Bar and therapeutic protocols, that ought to ideally embody irregular clinical trials to assess the efficacy of any intervention and live immune responses; and

(vi) Regulative compliance, together with institutional review board approval, which may vary relying on location. Ideally, the employment of convalescent liquid body substance would involve multiple centers, follow irregular management protocols, and have one center as a administration . every of these conditions ought to be on the market in developed areas plagued by COVID-19. a minimum of 1 pharma, Takeda, is wheelwork up to urge protein preparations against SARS2- CoV-2 from COVID-19 convalescent sera (28). 
We anticipate that once the desired regulative permissions are in place, people United Nations agency pass though COVID-19 are usually approached to give blood for liquid body substance preparation or protein isolation through apheresis. Recovery from COVID-19

are getting to be assessed clinically, and such people should be shown to free of SARS-CoV-2, together with in their blood by applicable microorganism supermolecule screening. given blood merchandise are getting to be screened for infectious agents in step with current blood banking practices, and individual sera are getting to be studied for specific protein content and neutralizing activity to SARS-CoV-2. relying on the volumes required and thus the neutralizing activity of given convalescent sera, these may well be pooled or used one by one, and preparations for clinical use would be treated for infective agent attenuation.

\section{CONCLUSION}

COVID-19 convalescent sera could be accustomed treat people with early symptoms and stop sickness in those exposed. Today, nurses, physicians, and initial responders exposed to proverbial cases of COVID-19, variety of whom have developed sickness, square measure being segregated , that threatens to collapse the health care system. it's anticipated that convalescent humour can forestall SARS-CoV-2 infection in those to whom it's administered. If this is often established, people UN agency receive convalescent sera might even be able to avoid a amount of quarantine. this may enable them to continue their crucial perform as health care suppliers. Convalescent sera might even be accustomed forestall sickness among relations caring for COVID-19 patients reception. Clearly, the employment of convalescent humour would be a makeshift live that might be used within the interior of this epidemic. Hence, as we have a tendency to square measure at intervals the interior of a worldwide pandemic, we have a tendency to advocate that establishments think about the emergency use of convalescent sera and begin preparations as before long as attainable. Time is of the essence.

\section{REFERENCES}

1. Hawkins D, Knowles H, Brice-Saddler $M$ et al. US coronavirus death toll reaches 17; at least half of US states confirm cases. Washington Post 2020.

https://www.washingtonpost.com/world/2020/03/ 06/coronavirus-liveupdates.Accessed 7 Mar 2020.

2. Blooberg. China finds promising coronavirus treatment in blood plasma. Fortune. February 14, 2020. https://fortune.com/2020/02/14/chinacoronavirus-treatment-blood-plasma-recoveredpatients/.Accessed 7 Mar 2020.
3. Report of the WHO-China Joint Mission on Coronavirus Disease 2019(COVID-19). 16-24 February 2020. https://www.who.int/docs/defaultsource/coronaviruse/who-china-joint-mission-oncovid-19-final-report.pdf.

4. Chang JC. Sepsis and septic shock: endothelial molecular pathogenesis associated with vascular microthrombotic disease. Thromb J. 2019;17:10.https://doi.org/10.1186/s12959-0190198-4.

5. Gyawali B, Ramakrishna K, Dhamoon AS. Sepsis: the evolution in definition,pathophysiology, and management. SAGE Open Med. 2019;7:2050312119835043. Published 2019 Mar 21. https://doi.org/10.1177/ 2050312119835043.

6. Hou PC, Filbin MR, Wang H, et al. Endothelial permeability and hemostasisin septic shock: results from the ProCESS trial. Chest. 2017;152(1):22-31.

7. Johansson P, Stensballe J, Ostrowski SR. Shock induced endotheliopathy (SHINE) in acute critical illness - a unifying pathophysiologic mechanism. Crit Care. 2017;21:25 https://doi.org/10.1186/s13054-017-1605-5.

8. Nguyen T, Carcillo J. Bench-to-bedside review: thrombocytopenia-associated multiple organ failure - a newly appreciated syndrome in the critically ill. Crit Care. 2006;10(6):235. https://doi.org/10.1186/cc5064.

9. Knaup H, Stahl K, Schmidt BMW, et al. Early therapeutic plasma exchange in septic shock: a prospective open-label nonrandomized pilot study focusing on safety, hemodynamics, vascular barrier function, and biologic markers. Crit Care. 2018;22:285 https://doi.org/10.1186/s13054-0182220-9.

10. Casadevall A, Scharff MD. Return to the past: the case for antibody-based therapies in infectious diseases. Clin Infect Dis. 1995;21(1):150-161.

11. Casadevall A, Dadachova E, Pirofski LA. Passive antibody therapy for infectious diseases. Nat Rev Microbiol. 2004;2(9):695-703.

12. Zhang JS, et al. A serological survey on neutralizing antibody titer of SARS convalescent sera.J Med Virol. 2005;77(2):147-150.

13. Beigel JH, et al. Safety and tolerability of a novel, polyclonal human anti-MERS coronavirus antibody produced from transchromosomic cattle: a phase 1 randomised, double-blind, single-dose-escalation study. Lancet Infect Dis. 2018;18(4):410-418.

14. Robbins JB, Schneerson R, Szu SC. Perspective: hypothesis: serum $\operatorname{Ig} G$ antibody is sufficient to confer protection against infectious diseases by inactivating the inoculum. $J$ Infect Dis. 1995;171(6):1387-1398.

15. Casadevall A, Pirofski LA. Antibody-mediated regulation of cellular immunity and theinflammatory response. Trends Immunol. 2003;24(9):474-478.

16. Park WH. Therapeutic use of antipoliomyelitits serum in preparalytic cases of poliomyelitis. JAMA. 1932;99:1050-1053. 
17. Park WH, Freeman RG. The prophylactic use of measles convalescent serum. JAMA. 1926;87(8):556-558.

18. Gallagher JR. Use of convalescent measles serum to control measles in a preparatoryschool. Am J Public Health Nations Health. 1935;25(5):595598.

19. Rambar AC. Mumps; use of convalescent serum in the treatment and prophylaxis of orchitis. Am J Dis Child. 1946;71:1-13.

20. Luke TC, Casadevall A, Watowich SJ, Hoffman SL, Beigel JH, Burgess TH. Hark back:passive immunotherapy for influenza and other serious infections. Crit Care Med.2010;38(4 suppl):e66e73.

21. Luke TC, Kilbane EM, Jackson JL, Hoffman SL. Meta-analysis: convalescent blood products for Spanish influenza pneumonia: a future H5N1 treatment? Ann Intern Med. 2006;145(8):599609.

22. Hung IF, et al. Convalescent plasma treatment reduced mortality in patients with severe pandemic influenza A (H1N1) 2009 virus infection. Clin Infect Dis. 2011;52(4):447-456.

23. Gajic $O$, et al. Transfusion-related acute lung injury in the critically ill: prospective nested case-control study. Am J Respir Crit Care Med. 2007;176(9):886-891.

24. Wan Y, et al. Molecular mechanism for antibodydependent enhancement of coronavirus entry. $J$ Virol. 2020;94(5):e02015-19.

25. Mair-Jenkins J, et al. The effectiveness of convalescent plasma and hyperimmune immunoglobulin for the treatment of severe acute respiratory infections of viral etiology: a systematic review and exploratory meta-analysis. J Infect Dis. 2015;211(1):80-90.

26. China puts 245 COVID-19 patients on convalescent plasma therapy. News release. Xinhua. February 28, 2020. Accessed March 10, 2020. http://www.xinhuanet.com/english/202002/28/c_138828177.htm.

27. Crowe JE, Firestone CY, Murphy BR. Passively acquired antibodies suppress humoral but not cell-mediated immunity in mice immunized with live attenuated respiratory syncytial virus vaccines. J Immunol. 2001;167(7):3910-3918.

28. Hopkins JS. Drugmaker Takeda Is Working on Coronavirus Drug. Wall Street Journal. https://www.wsj.com/articles/drugmakertakedais-working-on-coronavirusdrug- 11583301660. Published March 4, 2020. Accessed March 10, 2020. 